\title{
Other factors may effect the relationship between heart rate variability indices and coronary atherosclerosis
}

\author{
Ertugrul Kurtoglu $\cdot$ Sevket Balta
}

Received: 21 December 2013/Accepted: 4 February 2014/Published online: 22 February 2014

(C) Springer-Verlag Berlin Heidelberg 2014

In their article, Simula et al. [1] investigated the association of severity and extent of coronary atherosclerosis with heart rate variability (HRV) parameters and found that there is a shift of cardiac autonomic regulation towards sympathetic predominance in asymptomatic patients with coronary artery disease in which there is no evidence of myocardial ischemia. Although the authors excluded subjects with diabetes, Parkinson's disease, or atrial fibrillation, there exist other factors which may effect HRV such as diastolic dysfunction, thyroid disorders, peripheral artery disease, chronic obstructive pulmonary disease, anemia, and especially psychosocial factors such as stressful life events, general stress, hostility, depression, and anxiety [2-7]. In addition, it would have been very helpful to assess whether the presence of stenosis proximal to the origins of or within the sinoatrial node artery and the atrioventricular node artery associates with autonomic dysfunction.

Conflict of interest There is no conflict of interest.

\section{References}

1. Simula S, Vanninen E, Lehto S, Hedman A, Pajunen P, Syvänne M, Hartikainen J (2013) Heart rate variability associates with asymptomatic coronary atherosclerosis. Clin Auton Res [Epub ahead of print]. doi:10.1007/s10286-013-0220-z

2. Poanta L, Porojan M, Dumitrascu DL (2011) Heart rate variability and diastolic dysfunction in patients with type 2 diabetes mellitus. Acta Diabetol 48:191-196. doi:10.1007/s00592-011-0256-2

3. Kaminski G, Makowski K, Michałkiewicz D, Kowal J, Ruchala M, Szczepanek E, Gielerak G (2012) The influence of subclinical hyperthyroidism on blood pressure, heart rate variability, and prevalence of arrhythmias. Thyroid 22:454-460. doi:10.1089/thy. 2010.0333

4. Goernig M, Schroeder R, Roth T, Truebner S, Palutke I, Figulla HR, Leder U, Voss A (2008) Peripheral arterial disease alters heart rate variability in cardiovascular patients. Pacing Clin Electrophysiol 31:858-862. doi:10.1111/j.1540-8159.2008.01100.x

5. Corbo GM, Inchingolo R, Sgueglia GA, Lanza G, Valente S (2013) C-reactive protein, lung hyperinflation and heart rate variability in chronic obstructive pulmonary disease: a pilot study. COPD 10:200-207. doi:10.3109/15412555.2012.710667

6. Yokusoglu M, Nevruz O, Baysan O, Uzun M, Demirkol S, Avcu F, Koz C, Cetin T, Hasimi A, Ural AU, Isik E (2007) The altered autonomic nervous system activity in iron deficiency anemia. Tohoku J Exp Med 212:397-402. doi:10.1620/tjem.212.397

7. Thayer JF, Yamamoto SS, Brosschot JF (2010) The relationship of autonomic imbalance, heart rate variability and cardiovascular disease risk factors. Int J Cardiol 141:122-131. doi:10.1016/j. ijcard.2009.09.543

E. Kurtoglu $(\bowtie)$

Department of Cardiology, Malatya State Hospital, Ankara Cad.

Ozalper Mah, 44100 Malatya, Turkey

e-mail: erkurtoglu@hotmail.com

S. Balta

Department of Cardiology, Eskisehir Military Hospital,

Eskisehir, Turkey 